\section{ECONOMICS}

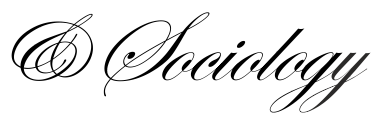

Tung, L. T. (2018). Impact of remittance inflows on trade balance in developing countries. Economics and Sociology, 11(4), 80-95. doi:10.14254/2071-789X.2018/11 $4 / 5$

\title{
IMPACT OF REMITTANCE INFLOWS ON TRADE BALANCE IN DEVELOPING COUNTRIES
}

\author{
Le Thanh Tung, \\ Faculty of Economics and Public \\ Management, Ho Chi Minh City \\ Open University, Ho Chi Minh \\ City, Vietnam. \\ E-mail:tung.lt@ou.edu.vn
}

ORCID: 0000-0001-8487-2217

Received: June, 2018

1st Revision: September, 2018

Accepted: November, 2018

DOI: $10.14254 / 2071-$

789X.2018/11-4/5
ABSTRACT. Remittances have been fastly increasing in developing world over the past decades, however, there is only a few evidence about the relationship between remittance inflows on the trade balance in the recipient countries. Our paper investigates the effect of remittance inflows on trade balance with a sample including 17 countries in the Asia-Pacific region in the period 19802015, which now is the largest recipient group compares others but there is no study in the region-level. The estimated results of the OLS, 2-SLS and PGMM regressions also strongly indicated a new evidence that remittance inflows had a negative effect on the trade balance of the countries in the sample. Furthermore, our results confirmed that the annual GDP per capita growth negatively affected on the trade balance which implies that the growth of income maybe leads to rising the imports values and imbalance in international trade of countries. However, the impact of exchange rate on the trade balance was a positive one in the case of the Asia-Pacific region. Our paper has provided new evidence which could help the policymakers in order to have some solutions to enhance the efficiency of remittance inflows to the economies in the future.

JEL Classification: F13, F15, F24
Keywords: trade balance, remittance inflows, GDP per capita, exchange rate, trade policy, recipient countries, developing countries, Asia-Pacific region. 


\section{Introduction}

For doing the economic development and growth targets require many people to find and move where the jobs are staying (from lagging to leading regions within a country or across national borders or maybe go around the world). In fact, labor is the main resource of the vast majority of the world's poor, and migration offers the best opportunity for finding a better job (or any job help earning money) and thereby having opportunities to escape poverty and out of unemployment (World Bank, 2016a). Nowadays, the migrants is an important issue which attracts more and more the attention from the economists worldwide. There are 250 million international migrants around the world and there have more than 150 million international migrants (approximately as $60 \%$ of the total number) are classified as workers (World Bank, 2016a). Besides, the statistics of the World Bank pointed that there had an increase in the share of immigrants in the world's population from $2.4 \%$ in 1960 to $3.3 \%$ in 2015 . The number of migrants has increased vastly in the past few decades for some main reasons: finding job opportunities, labor shortages resulting from falling birth rates, go outside of the country because of internal conflict, natural disasters, climate change, etc (World Bank, 2016a). The international migrants are now sending the money from their earnings back to their families in developing countries (their host countries). So in the near decades, the remittance inflows were having an important role in order to support the economic growth and reduce the poverty rate in many recipient countries worldwide (especially in the group of developing countries).

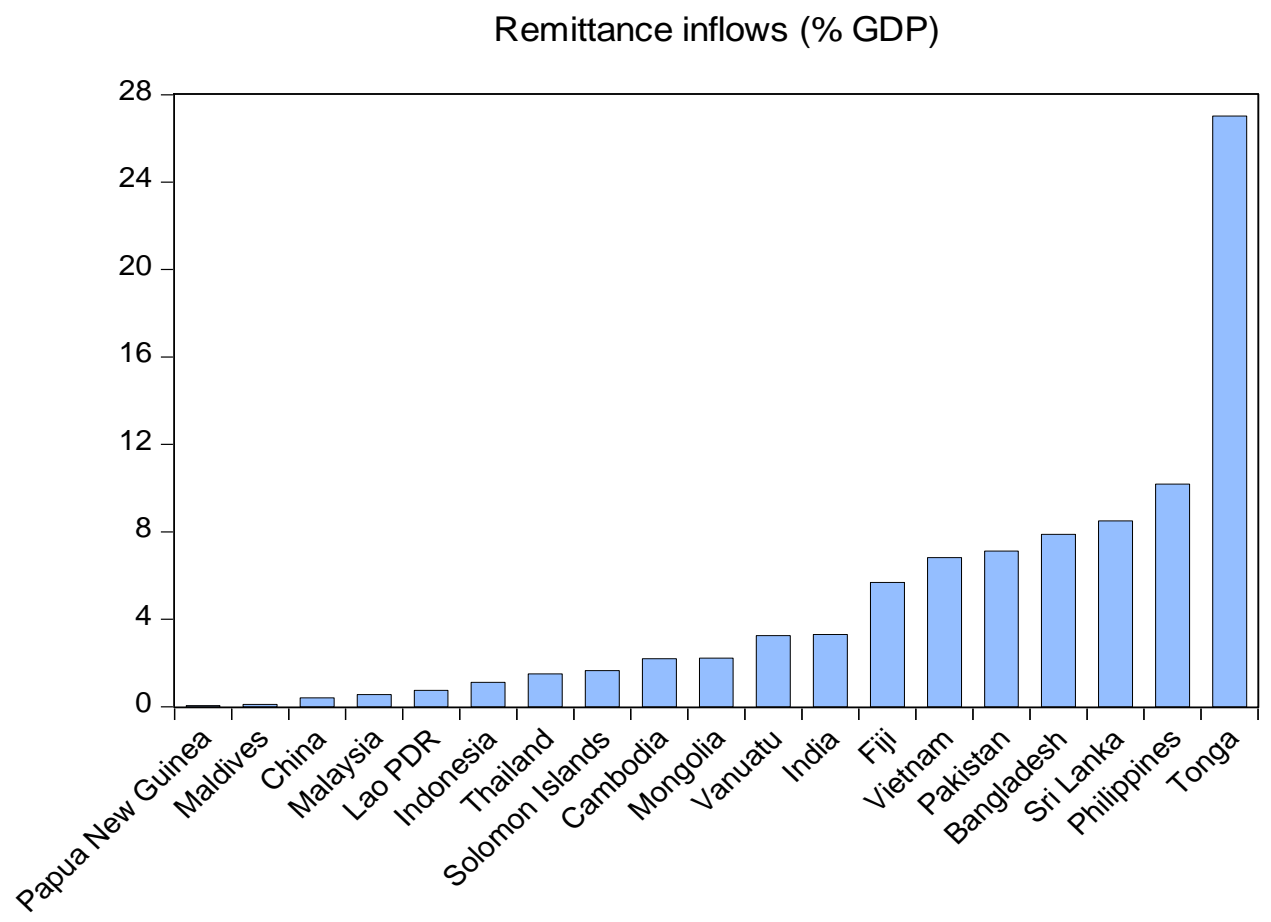

Graph 1. Remittance inflows of the countries in the Asia-Pacific region, 2015

Source: The author calculates from research data (World Bank, 2017)

Based on the statistics of Migration and Remittances report (World Bank, 2016b), global remittances were calculated to reach at $\$ 601$ billion in 2015 , in particular, the developing countries were received $73.37 \%$ of the total, which was about $\$ 441$ billion. The remittances inflows increased nearly three times compared the Official development assistance (ODA) value coming to the group of developing countries in the same period. Because of the large cost 
for sending of remittances between countries (in some case, it costs reaching $20 \%$ of the sending value) so the economists could not clearly know about the exact quantity of the remittance inflows which were believed to be significantly larger because these had much money go through informal channels (World Bank, 2016b). The report also continuously announced that the remittances had been leading to increased investments in health, education, and small businesses in various communities in receiving countries. Besides, it could generate more numerous benefits for the social, including increased trade, investment, knowledge, and technology transfers from diaspora contributions (World Bank, 2016b).

Furthermore, based on the statistics from the World Bank (World Bank, 2017), we calculate that the Asia-Pacific region is the world's largest remittances within the previous decade, in particularly, this region had the total remittance inflows have estimated to reach $\$ 254$ billion in 2015 (accounting for 43.6\% of the total developing world) which had an increase of $4 \%$ compared previous year. Besides, the remittance inflows to the Asia-Pacific region had fastly increased by 18 times, from $\$ 14.2$ billion in 1990 to $\$ 244$ billion in 2015 . Besides, the Asia-Pacific region has twenty countries which have the rate of remittance inflow over the Gross domestic product (GDP) are higher than 1\% in 2015, in particular, it exceeds 5\% of GDP in seven countries in this region (see Graph 1). There is an information which is more impressive that there are five countries (including India, China, Philippines, Pakistan, and Bangladesh) in this region listed in the group of Top-ten remittance-receiving countries in the world (ranked by the receiving value).

Because of the significant increase of remittances worldwide so there are many studies focus on its impact on macro issues in the received economies or recipient regions. We have diversified evidence which investigates that that remittance inflows can support the economic growth by providing an alternative financial channel the formal channels to finance investment as well as helping overcome liquidity constraints in household's businesses (Giuliano \& RuizArranz, 2009) or remittances can raise the total consumption of recipient countries and maybe increase the aggregate demand by a multiplier effect (Rausser et al., 2018) reducing effect on poverty because remittances help the recipient households have a higher income (Acosta et al., 2008), raising the competitiveness by increasing investment in human capital which could also increase productivity as well as the competitive level of the receiving economy (Bayangos \& Jansen, 2011), extend the financial market because remittance flows were contributing positively to the development of the financial system in the receiving economy (Chowdhury, 2011) or increase the efficiency of banking systems which leads to a better credit environment for domestic companies (Cooray, 2012).

In the other hand, we also have some results that confirm remittance inflows can make some negative effects on the recipient economies including an increase in social inequality level in the case of poor countries because the remittance-receiving households might have a higher income than others (Acosta et al., 2008), enhance the corruption in the non-OECD countries (Berdiev et al., 2013), speeding up the inflation (Narayan et al., 2011; Tung et al., 2015) negative impact on private investment because remittances might lead to a moral hazard or dependency syndrome situation which could prompt the recipients to reduce their participation in productive and business activities (Mallick, 2012) or reduce the productivity of the economy and cut-out the motivation of receiving-remittance employee (reduce recipients' economic incentive to work) as well as participate in the labor market, which results in a net harmful effect on growth and was a complex challenging for recipient countries (Le, 2009). As one of the international financial resources, remittances can support the international trade between related countries, however, we only have got very few evidenced focused on the impact of remittance inflows on trade balance or international trade worldwide, in particular, there is no evidence in the Asia-Pacific developing countries (which is the largest received region in the 
world now). However, there was several evidence in Africa (eg, Bourdet \& Falck, 2006) which had suggested that remittance inflows could lead to an inflation of the price of non-tradables and increase of the exchange rate, which could reduce the competitiveness of exports (this situation could be called as the Dutch Disease phenomenon) as well as support the imports of foreign products. Besides, the evidence maybe is in a country-level and there is a lack of evidence in the large sample of countries. So we expect our article will have a new contribution to the literature effects of remittances because it is the first investigated evidence focus on the impact of remittance inflows on trade balance which use a sample including seventeen developing countries in the Asia-Pacific region.

The content of our paper has five sections. In Section 1, we will have a review of the literature. Section 2 shows the econometric equation, methodology, and data description. Section 3 represents the regression results as well as discussion. Section 4 concludes some highlights and suggestions for the policymakers in recipient economies.

\section{Literature review}

Because there is a strong increase in the trend of remittance inflows to the developing countries in the Asia-Pacific region so there are some investigated results of this phenomenon in previous studies, example, remittance inflows can reduce the poverty (Hatemi-J \& Uddin, 2014), enhance the accessibility to financial sector (Inoue \& Hamori, 2106), link to the business cycle (Jha et al., 2010; Mughal \& Ahmed, 2014), raise the inflation (Tung et al., 2015) increase the households's consumption (Petrou \& Connell, 2016), change the exchange rate (Prakash \& Mala, 2015) or harm private investment (Mallick, 2012). Although the high openness of international trade in the Asia-Pacific region, however, there is no evidence about the relationship between remittance inflows and trade balance (or trade flows) done in a large sample of countries in this region. We can review some investigated studies in other region or in only a country-level in Asia region. Overview in the general, there has more empirical studies in Africa (or Eastern European) than Asia or Pacific region, however, the evidence in Africa, as well as Eastern European region, are also fuzziness.

In the Asia region, Bhatta (2013) used the Error correction model to examine the effect of remittance inflow and trade deficit in Nepal with a monthly database in the period of 20012011. The cointegration test showed that there was a relationship between remittances and trade deficit (as well as remittances and imports) in long-run. Besides, the results confirmed that remittance inflow caused the merchandise import and trade deficit to rise in Nepal's economy. The evidence in this study implied that remittance inflows could lead the economy to some macro risks including trade deficit in the long run and entangle in a remittance-import trap. In another study in Nepal, Dahal (2014) continuously concluded that increasing inflows of remittances had a negative association with international trade in the period 1995-2011. The author had pointed two kinds of negative impacts of remittance inflows on international trade including the decreasing of export competitiveness through exchange rate appreciation and discourage of the tradable sector because of the high price of non-tradable products due to the decrease of the labor supply. Besides, the author found that remittances had a positive association with entrepreneurship, however, a negative association with manufacturing. Finally, the paper indicated a mixed (both positive and negative) effect of remittance inflows on economic growth in Nepal.

Investigating an economy in Southeast Asia, Hien (2017) studied the impact of remittance inflows on Malaysia's trade balance in the period of 1990-2015. Showing on the literature review, remittances are foreign currency flows coming to recipient economies so they can make a depreciation situation in the exchange rate of the economies. However, the 
quantitative result confirmed the remittance inflows had positively influenced on the trade balance in the case of the Malaysia economy. The result also found that the real exchange rate had a positive impact on the balance of trade. Furthermore, the study result also implied that Malaysia was not faced a symptom of Dutch disease (in which, the exchange rate was affected by the flow of remittances).

In Africa, Bourdet and Falck (2006) did a study in Cape Verde where had the emigrants' remittances had increased rapidly over the past decades. The research result concluded that remittances gave a rising in the common price related to a sort of Dutch Disease effect and thereby had an adverse effect on the competitiveness of the tradable sector. The authors also suggested that remittance inflows could lead to an increase in the price of non-tradables as well as the exchange rate. This situation could reduce the competitiveness of exports as well as support the imports of foreign products. So the remittance inflows might have a negative effect on the trade balance in the recipient countries. In Sub-Sahara Africa region, Okodua and Olayiwola (2013) showed that remittance inflows had a negative impact with trade balance with a sample having 30 countries in the period 2002-2011, however, the results were statistically insignificant effect in the regressions. Because of the statistical insignificance of the estimated coefficient, so the authors could not conclude about the effect of remittance inflows on the trade balance in developing countries in Africa.

Focusing on the case of the Kenyan economy, Kagochi and Kiambigi (2012) used the annual data in the period 1970-2008 to study the relationship between remittance inflow and the housing construction market. Based on their results which found that inbound remittances led to a rising in housing construction demand, we might consider that remittances could take an increasing demand for the imports of construction materials using in the market. So the trade balance maybe hurt by remittance inflows to the economies. Olubiyi (2014) did a study in order to examine the causal relationships between gross domestic product, exports, imports and trade in Nigeria in the time of 1980-2012. The quantitative result implied that remittances had a negative effect on exports and a positive effect on imports, so we could think that remittances had a negative impact on the trade balance in the case of the Nigerian economy. Farzanegan and Hassan (2016) identified the role of remittances in the trade balance with a sample including eleven countries in the Middle Eastern and North Africa (MENA) region in 1980-2013. They found that the inflow of remittances had an increasing effect on trade deficit (or negative effect on trade balance) by triggering imported-led consumption expenditures in the economies. The result confirmed that the policymakers in this region have managed to increase the domestic investment capacity might be able to reduce the negative trade balance effects of remittances.

With an empirical study in the Eastern European region, Jovičić and Mitrovíc (2006) discussed in the case of Serbia which is that the large and growing foreign trade deficit was obviously financed partly by substantial remittance inflows. Besides, the result implied that large remittance inflows maybe lead to a reduction in domestic production competitiveness. With a survey in Macedonia, Muhal et al. (2008) pointed out that the largest part in the household's expenditure (from remittances) was used for durable goods than for any other item. The result implied that remittances could increase the imports (for durable products from outside) as well as make a deficit in the trade balance. Stratan and Chistruga (2012) had concluded that the remittance inflows in Moldova might explain the international reserves accumulation as well as put this economy under-appreciation. After that, the domestic economic competitiveness has been weakened and constraining national exports (decreased exports competitiveness).

In the worldwide level, Vaaler (2011) presented an research evidence between remittances and economic internationalization level with a sample of 61 developing countries of some continental in 2002-2007. The investigated result showed that remittances could 
increase the openness to international trade in recipient countries. In detail, the quantitative analysis presented that a standard deviation increase in remittances would increase economic internationalization level by $9.8 \%$. The economic internationalization level in a country was measured as the total volume of exports and imports divided by GDP. Finally, the author concluded that the remittances played an important role in raising the integration level of recipient countries with the world economy. However, the paper had not got any evidence between remittances and trade balance situation in the economies in the study period.

\section{Methodological approach and data description}

\subsection{Methodology approach}

The estimation strategy of our paper is presented in this section which includes general function, some specific models as well as the estimated methodology. Based on the literature review, in order to examine the impact of remittance inflows on the trade balance in the AsiaPacific region, we present the Trade balance equation as the function form:

$$
\text { Trade }=\mathrm{f}(\text { GGDPPER, Remittance } \mathrm{s} \text {, Exchange })
$$

To deeply investigate the relationship between remittance inflows and trade balance in the sample, we will try to estimate this function with some forms which have a difference in the number of the variables. The function (1) can be expressed as the four following forms:

$$
\begin{aligned}
& \text { Trade }_{\mathrm{i}, \mathrm{t}}=\alpha_{01}+\alpha_{11} \text { Remittance }_{\mathrm{i}, \mathrm{t}}+\varepsilon_{1 \mathrm{i}, \mathrm{t}} \\
& \text { Trade }_{\mathrm{i}, \mathrm{t}}=\alpha_{02}+\alpha_{12} \text { GGDPPER }_{\mathrm{i}, \mathrm{t}}+\alpha_{22} \text { Remittance }_{\mathrm{i}, \mathrm{t}}+\varepsilon_{2 \mathrm{i}, \mathrm{t}} \\
& \text { Trade }_{\mathrm{i}, \mathrm{t}}=\alpha_{03}+\alpha_{13} \text { Remittance }_{\mathrm{i}, \mathrm{t}}+\alpha_{23} \text { Exchange }_{\mathrm{i}, \mathrm{t}}+\varepsilon_{3 \mathrm{i}, \mathrm{t}} \\
& \text { Trade }_{\mathrm{i}, \mathrm{t}}=\alpha_{04}+\alpha_{14} \text { GGDPPER }_{\mathrm{i}, \mathrm{t}}+\alpha_{24} \text { Remittance }_{\mathrm{i}, \mathrm{t}}+\alpha_{34} \text { Exchange }_{\mathrm{i}, \mathrm{t}}+\varepsilon_{4 \mathrm{i}, \mathrm{t}}
\end{aligned}
$$

Where: Trade $_{\mathrm{i}, \mathrm{t}}$ measures the trade balance of the economies, GGDPPER $\mathrm{i}_{\mathrm{i}, \mathrm{t}}$ presents the annual GDP per capita growth, Remittances $\mathrm{s}_{\mathrm{i}, \mathrm{t}}$ is denoted remittance inflows, Exchange $\mathrm{e}_{\mathrm{i}, \mathrm{t}}$ is the exchange rate and $\varepsilon_{i, t}$ is the error term. We have $t$ denotes time periods, and $i$ is cross-sectional units with $i \epsilon[1, N]$. There are some different measuring kinds for the variables in the equations. The definitions and the unit of variables are reported in the below table.

Table 1. The definition and source of variables

\begin{tabular}{llc}
\hline Variable symbol & \multicolumn{1}{c}{ Definition } & Unit \\
\hline Trade & $\begin{array}{l}\text { Trade balance is calculated by exports minus imports (\% of } \\
\text { GDP) }\end{array}$ & $\%$ \\
\hline GGDPPER & Annual GDP per capita growth & $\%$ \\
\hline Remittances & $\begin{array}{l}\text { Personal remittances received is denoted the variable of } \\
\text { remittance inflows (\% of GDP) }\end{array}$ & $\%$ \\
\hline Exchange & $\begin{array}{l}\text { Official exchange rate (Local country's currency per USD, } \\
\text { period average) }\end{array}$ & LCC/USD \\
\hline
\end{tabular}

Source: World Development Indicators (World Bank, 2017)

In order to successfully do the study targets, we apply three methods including the Ordinary Least Squares (OLS), the Two-stage least squares (2-SLS) and the Panel Generalized Method of Moments (PGMM) methodology for estimating the econometric equations. Besides, 
each estimated method will be employed in some different models and each result is compared with other to have the answering about the exact effects amongst variables.

The estimation strategy has two main steps. In the first step, the OLS is used with both the Fixed effect model (FEM) and the Random effect model (REM), after that, the Hausman test is employed to choose which is better result between the Fixed effect and the Random effect (Hausman 1978). In the case, the null hypothesis is rejected (when we have the p-value is $<0.05$ ), the testing result confirms that the result of the Random effect is biased and the Fixed effect is the better one, otherwise, we will conclude the Random effect is chosen. In the second step, based on some suggestions about the endogenous phenomenon which could be done between some variables in the estimation progression, this situation leads to violating the assumptions of a good linear regression model. The endogenous phenomenon in the regression continuously leads to biased estimates in the econometric result. In this case, the instrumental variable techniques are commonly used to address this problem. So the econometric equations will be estimated by the 2-SLS and the PGMM method which can solve the endogeneity in the econometric model, besides, we can use the OLS's result for comparison. We continuously estimate the functions with the Fixed effect and the Random effect model and use the Hausman test in order to choose which is the better one in the results. Following the literature studies, in the 2-SLS and the PGMM techniques, we will replace the endogenous variables in the econometric function by their lag values (see Vella and Verbeek 1999). Finally, the 2-SLS and the PGMM regressions will correct for the possible endogeneity problems in our econometric model and the results are enough reliability to have some implications for the policymaking process in the future.

\subsection{Data description}

In our paper, the database is employed by an annual panel form in the period 1980-2015 which includes seventeen recipient countries in the Asia-Pacific region. The sample excludes some countries in this region because of the missing values in their indicators. All the variables are sourced and calculated from the World Development Indicators (World Bank, 2017). The World Development Indicators of the World Bank maybe is the most popular and reality source in the world.

Table 2. Descriptive statistics of variables

\begin{tabular}{lcccc}
\hline \multicolumn{1}{c}{ Statistic } & Trade & GGDPPER & Remittances & Exchange \\
\hline Mean & -5.731238 & 3.362344 & 4.311439 & 1351.558 \\
\hline Median & -4.973553 & 3.619256 & 2.326894 & 34.54349 \\
\hline Maximum & 25.05170 & 15.56779 & 36.41663 & 21697.57 \\
\hline Minimum & -50.51289 & -16.55813 & 0.012338 & 0.817965 \\
\hline Std. Dev. & 11.46577 & 3.974427 & 5.829586 & 3805.828 \\
\hline Skewness & -0.960342 & -0.817234 & 2.875642 & 3.283565 \\
\hline Kurtosis & 5.561921 & 6.027212 & 12.68672 & 13.59973 \\
\hline Jarque-Bera & 215.3018 & 248.5455 & 2665.106 & 3265.112 \\
\hline Probability & 0.000000 & 0.000000 & 0.000000 & 0.000000 \\
\hline Observations & 526 & 526 & 526 & 526 \\
\hline
\end{tabular}

Source: The author calculates from research data (World Bank, 2017)

In our sample, there are eleven countries in Asia (which are Bangladesh, Cambodia, China, Indonesia, India, Malaysia, Mongolia, Pakistan, Philippines, Thailand, and Vietnam) 
and six countries in Pacific (including Fiji, Maldives, Papua New Guinea, Solomon Islands, Tonga, and Vanuatu). However, there are other receiving- remittances countries in the AsiaPacific region are not collected on my database because of the small value in remittance inflows or the large missing in the remittances data. The descriptive statistics of variables are shown in the following table.

\section{Conducting research and results}

Following the econometric strategy is designed in the previous section, we apply three estimated methods (the OLS, 2-SLS, and PGMM) to estimate the trade balance equations. To comparison which is the better between the FEM or the REM result, our paper employs the Hausman test, however, all testing results confirm that the FEM results are chosen because the null hypothesis that the unobservable individual specific random errors are not correlated are rejected at the significance of $1 \%$ level. On the other hand, the R-squared values of the FEM regressions are more significant large than REM results, which are also the suggestions for the conclusion that the FEM method is better one. Although the checking results indicate that we can choose the FEM results to describe both the OLS and the 2-SLS regressions and the REMs for the PGMM, we can compare all of the estimated results to have multiple observation sides about the effect of remittances on the trade balance in the recipient countries in the Asia-Pacific region. However, the FEM and the REM results have unified about the relationships between trade balance and dependent variables with all estimated methods.

Table 3. The Ordinary Least Squares (OLS) estimation results

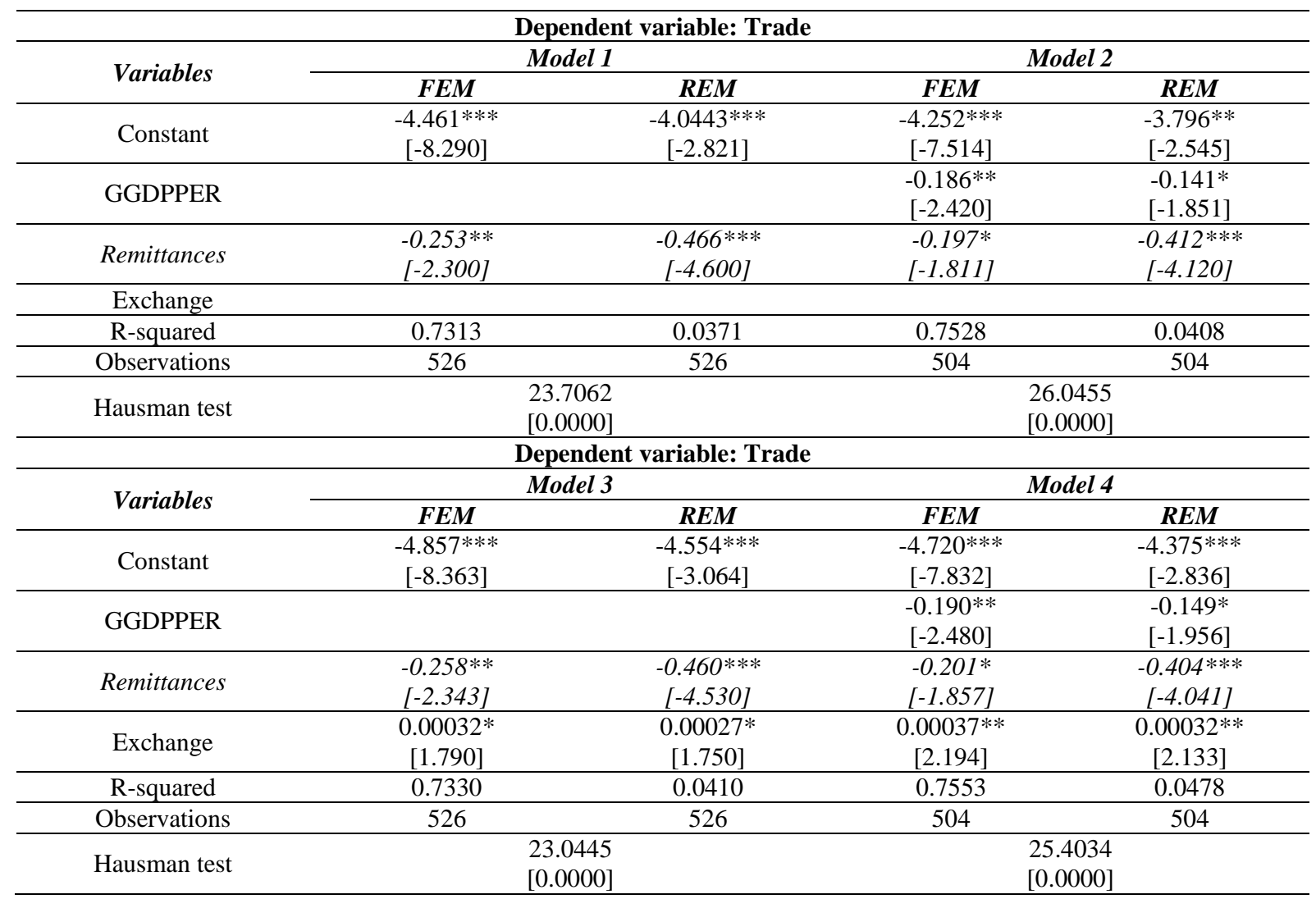

Notes: The t-statistics are in parentheses below the coefficients; $* * * * * *$ significant at $10 \%$, $5 \%, 1 \%$.

Source: The author calculates from research data (World Bank, 2017) 
and actual data in the Asia-Pacific region. However, the quantitative results and the fact is in the same way because our investigated finding is also suitable with Graph 2 viewing about the relationship between remittance inflows and the trade balance (done by our study statistics). In Graph 2, we can see that the number of observations which are negative relationships larger than positive points. The positive in remittance inflows is related by the negative in the trade balance. In particular, the trend could be summarized that the highest in values of remittance inflows might lead to the largest deficit in the trade balance of the recipient countries (we can see quite clearly at the left of Graph 2).

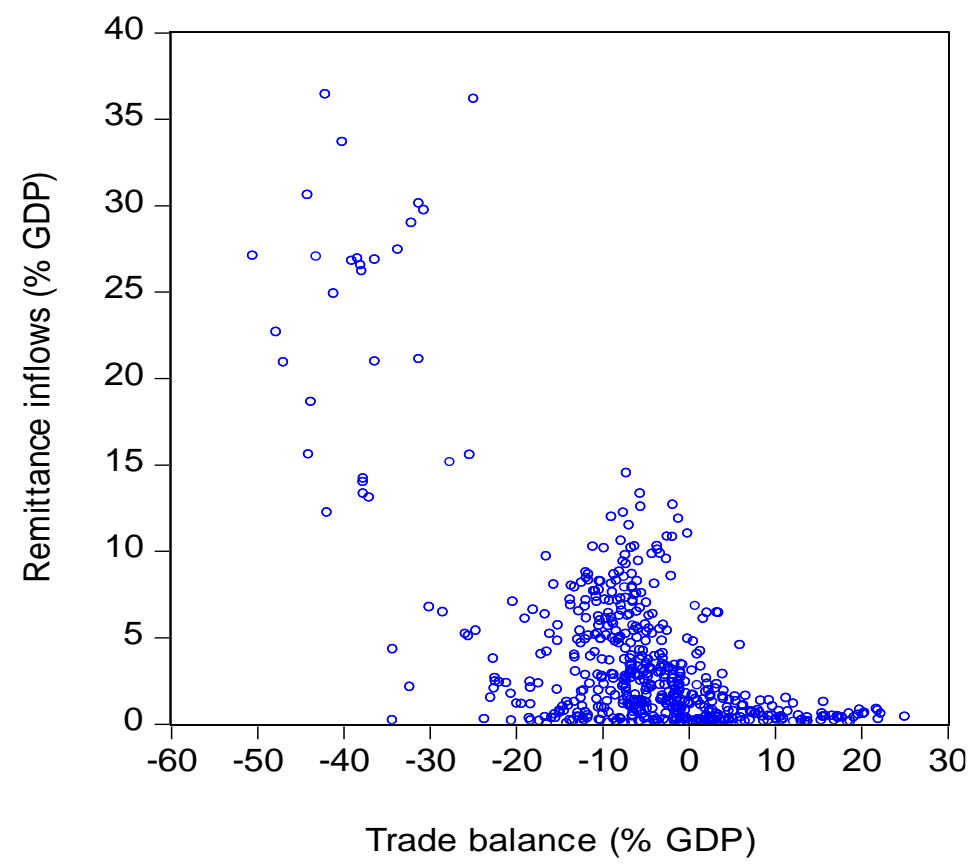

Graph 2. Remittance inflows and the Trade balance

Source: The author calculates from research data (World Bank, 2017)

The empirical evidence also suggests that remittance inflows have a significant harmful effect on the trade balance in the Asia-Pacific developing countries over previous decades. The results also implied that the increasing trend of remittance inflows could make a rising in the trade deficit in this region. Our evidence confirms the remittances maybe lead to dependency syndrome phenomenon which can take the receiving people to reduce their participation in the labor market or business activities. After that, these actions will reduce the productivity of the economy (and also the total output of the economy) and make more convenient conditions for the foreign products importing to the insides. The manufacturing is decreased can cause a falling in the national export value. These situations can also explain the negative effect of remittance inflows on the trade balance in the Asia-Pacific region.

Besides, remittances also lead to a decrease in the motivative level of the receivingremittance people and participate in the labor market. The result has provided a complex challenging for recipient countries in the context of fast increasing of the remittances in this region in the future. This finding is a valuable information for the policymakers in the recipient countries in the Asia-Pacific region because the remittance inflows are forecasted to reach a new record in the near future (World Bank, 2016b) which can be made many risks for the trade balance of the countries. Besides, our study data showed that there had got nine countries in the research sample (including seventeen countries) fall down the group which had the trade deficit 
in 2015 (World Bank, 2017). We can see (Graph 3) there is a larger in observations which describe a negative sign in the trade balance of the countries in the research sample.

Trade balance (\% GDP)

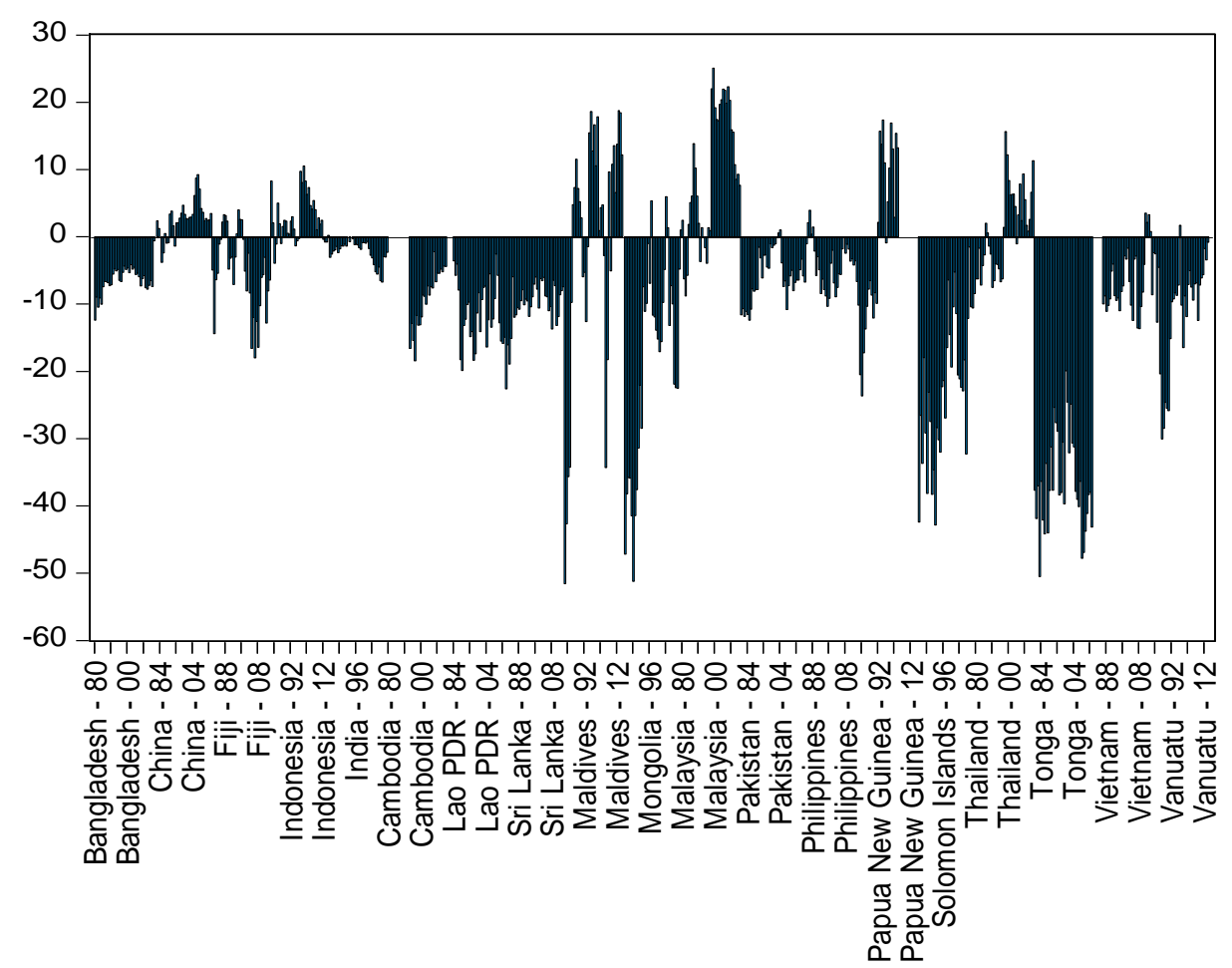

Graph 3. Trade balance of the countries

Source: The author calculates from research data (World Bank, 2017)

Our finding is consistent with the previous results in the evidence of the countries in the Sub-Sahara Africa (SSA) region (Okodua \& Olayiwola, 2013) or in the Middle Eastern and North Africa (MENA) region (Farzanegan \& Hassan, 2016). Our result is also supported by the studies done by specific country data in Nepal (Bhatta, 2013), in Serbia (Jovicic \& Mitrovic, 2006), in Nigeria (Olubiyi, 2014) or Kenya (Kagochi \& Kiambigi, 2012). However, our finding is inconsistent with the result in the case of Malaysia in the Asia region (Hien, 2017). Based on the estimated results, we can explain that the remittance inflows have a negative impact on trade balance because these financial resources flow in the Asia-Pacific countries which can raise the households' consumption for the expensive products come from the foreign countries. So the increasing of remittance inflows will make a positive effect on imports and the trade balance can be hurt in this situation (Olubiyi, 2014). Our estimated result clearly suggests that although the remittances to the Asia-Pacific having some exhibit impact to unbalance of international trade across the economies. This situation has made some worries about the large of deficit value because of the strong rising trend of remittance inflows in this region in the future.

Besides, when the economies start to import more and more foreign products which lead to an increase in the competitive level in the markets and the result is the domestic companies will be faced the more difficult to sell their products in the markets (Jovicic \& Mitrovic, 2006). Mallick (2012) also noted that remittance inflows maybe do a moral hazard or dependency syndrome situation which can prompt the recipients to reduce their participation in productive activities. So remittance inflows would result in an increase in private consumption without production impact which leads to a deficit in the trade balance. We can worry when the domestic 
companies spent their resources on the competitions with foreign products in the domestic market which can decrease the exports value of the economies (Olubiyi, 2014). Based on our investigated results as well as compared with the previous results, we can totally conclude that the remittance inflows had a negative impact on the trade balance in the Asia-Pacific countries. Furthermore, the result implies that remittances might be a problem for economic growth because the impact is more from the demand side and this problem can lead to inflationary pressure in the economy (can be known as a demand-pull inflation type). So we suggest a policy recommendation which was that the authorities should intensify efforts on the export base of the economy by the implement of some necessary policies to cool the pressure arising from the spending of remittances.

According to the estimation results of the OLS, 2-SLS, and PGMM, the evidence indicates that the growth of GDP per capita has a negative impact on the trade balance and the results are statistically significant. The finding implies the income per capita increases which will lead to a rising in both the imports as well as the trade deficit in the region. The income per capital increased in the Asia-Pacific region would encourage people to buy more imports product and led to a deficit in the trade balance (Duasa, 2007). The negative effect of the GDP per capita on trade balance can be explained by a reason when the income increases in the demand not only the foreign products but also the domestic products however many inputs of production progress must be imported. It is a meaning that the import demand of inputs will be raised and can make a larger deficit in the trade balance.

Our evidence makes a highlight point for the policymakers in the Asia-Pacific region that they need some urgent solutions to solve this situation because the GDP per capita may increase more fastly in this region which can lead to a larger deficit in the trade balance in the future. This finding is also united with previous studies, example, the research of Duasa (2007) found that the income had a negative impact on the trade balance in the short-run in the case of Malaysia (an economy in the Asia-Pacific region). The finding implies that domestic enterprises must have more motivate to link with the customers, expand markets as well as develop the distribution networks. Besides, the governments need to support domestic firms by some policies which focus on expanding trade environments, economic cooperation and provided effective support for the cooperation between domestic enterprises in the economy.

The estimation results found a positive effect of the exchange rate on the trade balance of in the Asia-Pacific region with three regressions (the results are also statistically significant). As we know that the remittances are the foreign currency inflows so they can make some pressures for the exchange rate policy in receiving countries because this policy has a target for an economy to manage its currency in respect to foreign currencies as well as the foreign exchange market. The remittances can be converted into the domestic currency or still living as the foreign currencies in the recipient economies. However, our finding indicates that the exchange policy in the research countries has had a valuable role in the way to balancing the international trade in this region. In particular, our paper has provided a new evidence about the effect of exchange rate on trade balance with a large sample of the countries in the Asia-Pacific region. The estimated results are supported by a number studies investigated in some specific economies in the Asia-Pacific economies which are the case in Thailand and Malaysia (Baharumshah, 2001), in Bangladesh (Aziz, 2008), in Vietnam (Trinh, 2014) or in Malaysia (Hien, 2017). Our result also suggests that the governments of recipient countries need to have a perseverance in the way to implement their exchange rate policy. Because our finding has demonstrated the correction of this policy in the role to support the international trade in this region. 


\section{Conclusion}

The Asia-Pacific is the largest remittance recipient region in the world, however, there is no evidence about the impact of remittance inflows on the trade balance in this region. To filling this empirical gap in the literature, we employe a sample having seventeen countries in the Asia-Pacific region with the data collected in 1980-2015. The estimation methods are the OLS, 2-SLS, and PGMM with ten regression models in order to clearly identify the effect of remittance inflows on the trade balance of the economies. Unlike many previous results which usually point to the positive effect of remittance inflows on the recipient countries, our results strongly show that the remittance inflows have a negative impact and statistically significant on the trade balance. Which also indicates a rising in the number of remittances can lead to an imbalance in the international trade in the Asia-Pacific region. The estimated results are significant statistics with a large number of regression models. The finding is supported by a number of studies in country-level or region-level in the literature. The regressions indicate that the growth of GDP per capita has a negative impact on the trade balance and the results are statistically significant which implies the income per capita increases can lead to a deficit in the trade balance in the region. Finally, we also find a positive effect of the exchange rate on the trade balance of in the Asia-Pacific region which confirms that the exchange rate policy has an efficiency in the countries in this region.

Furthermore, we can discuss some policy suggestions that come following our investigated results. Our results provide some the valuable information about the impact not only remittance inflows but also the income and exchange rate in the trade balance. Based on the results, the policymakers in these countries should try to do some policies which attract remittance inflows put more and more in the production sector or service sector (besides consumptions) for sustainable promoting the economic growth. In order to reduce the deficit in the trade balance, the governments might try to raise the competitiveness of domestic products (to replace the products from outsiders) by the supporting policies for the domestic companies. Besides, the governments should try to expand the financial system and banking system to attract more and more household's remittances to these systems, after that as the loan, the remittances can go to the companies of the economies in our research sample. Besides, the governments need have an attracting remittance inflows policy by specific projects for education, housing or business which can support their more productive in the using process. The improvement of the business environment in the receiving countries also encourage the return of migrants with their fresh capital, international relationships, new technology, new knowledge which can enhance the economic growth in the receiving countries.

Our study confirms that the exchange rate policy has an effective role in order to support the development of international trade or making a balance situation of trade value in the region. So the policymakers in the countries need to have more perseverance to do the exchange rate policy in the same ways in the long-run which can help the economies have more stable in the future. Besides, the governments can see clearly that the income in the countries will be continuously increased in the future, this trend can not deny, however, the income increases which leads to a trade deficit because the people maybe buy more foreign products. So the policymakers must be reinforced and motivate a stronger of the domestic production ability to substitute the foreign products by the domestic products at the same quality. This solution can help to reduce the deficit of trade balance in the long run.

Despite, we tried to deeply analysis the impact of remittance inflows on the trade balance individual balance, however, the specific effects on each export balance or import balance are not reflected. These issues need further researches to explore more about the impact of remittance inflows on the trade balance in the future. In the next studies, the relationships 
between remittance inflows and some macroeconomics in the Asia-Pacific region (eg., consumption or saving) need to continuously analysis to have a more clearly viewing about the ways that remittances can affect the macro indicators of recipient economies.

\section{Acknowledgment}

The author would like to kindly thank the financial supporting by the Ho Chi Minh City Open University in carrying out this research.

\section{References}

Acosta, P., Calderón, C., Fajnzylber, P., \& Lopez, H. (2008). What is the Impact of International Remittances on Poverty and Inequality in Latin America?. World Development, 36 (1), 89-114. doi: https://doi.org/10.1016/j.worlddev.2007.02.016

Aziz, N. (2008) The Role of Exchange Rate in Trade Balance: Empirics from Bangladesh, Working paper, University of Birmingham, UK, [online access at 15/08/2017] http://citeseerx.ist.psu.edu/viewdoc/download?doi=10.1.1.192.5571\&rep=rep1\&type=pd

Baharumshah, A. Z. (2001). The Effect of Exchange Rate on Bilateral Trade Balance: New Evidence from Malaysia and Thailand. Asian Economic Journal, 15 (3), 291-312. doi: https://doi.org/10.1111/1467-8381.00135

Bayangos, V., \& Jansen, K. (2011). Remittances and Competitiveness: The Case of the Philippines. World Development, 39 (10), 1834-1846. doi: https://doi.org/10.1016/

Berdiev, A. N., Kim, Y., \& Chang, C. P. (2013). Remittances and Corruption, Economic Letters, 118 (1), 182-185. doi: https://doi.org/10.1016/j.econlet.2012.10.008

Bhatta, G. R. (2013) Remittance and Trade deficit nexus in Nepal: A VEAM approach, NRB Working paper, No. 14, Nepal Rastra Bank.

Bourdet, Y., \& Falck, H. (2006). Emigrants' remittances and Dutch disease in Cape Verde. International Economic Journal, 20 (3), 267-284. doi: https://doi.org/10.1080/ 10168730600879323

Chowdhury, M. B. (2011). Remittances flow and financial development in Bangladesh. Economic Modelling, 28(6), 2600-2608. doi: https://doi.org/10.1016/j.econmod. 2011.07.013

Cooray, A. (2012). Migrant remittances, financial sector development and the government ownership of banks: Evidence from a group of non-OECD economies. Journal of International Financial Markets, Institutions and Money, 22(4), 936-957. doi: https://doi.org/10.1016/j.intfin.2012.05.006

Dahal, P. (2014). The impact of remittances on economic growth in Nepal: an analysis of a significant basis of development. Asia Pacific Journal of Public Administration, 36 (4), 261-282. doi: https://doi.org/10.1080/23276665.2014.975908

Duasa, J. (2007). Determinants of Malaysian Trade Balance: An ARDL Bound Testing Approach. Global Economic Review, 36(1), 89-102. doi: https://doi.org/10.1080/ 12265080701217405 
Farzanegan, M. R., Hassan, S. M. (2016). How does the Flow of Remittances affect the Trade balance of the Middle Eastern and North Africa?. Macie Paper series, Nr. 2016/13, Marburg Centre of Instituational Economics, Marburg, Germany.

Giuliano, P., \& Ruiz-Arranz, M. (2009). Remittances, financial development, and growth. Journal of Development Economics, 90 (1), 144-152. doi: https://doi.org/10.1016/ j.jdeveco.2008.10.005

Hatemi-J, A., \& Uddin. G. S. (2014). On the causal nexus of remittances and poverty reduction in Bangladesh. Applied Economics, 46 (4), 374-382. doi: https://doi.org/10.1080/ 00036846.2013.844331

Hausman, J. A. (1978). Specification Tests in Econometrics. Econometrica, 46 (6), 1251-1271. doi: https://www.jstor.org/stable/1913827

Hien, N. P. (2017). The Impact of Remittance on Trade Balance: The Case of Malaysia. Journal of Economics and Public Finance, 3 (4), 531-540. doi: 10.22158/jepf.v3n4p531

Inoue, T., \& Hamori, S. (2016). Do Workers' Remittances Promote Access to Finance? Evidence from Asia-Pacific Developing Countries. Emerging Markets Finance and Trade, 52 (3), 765-774. doi: https://doi.org/10.1080/1540496X.2016.1116287

Jovičić, M., Mitrovíc, R. D. (2006). Macroeconomic analysis of Causes and Effects of Remittances: A panel model of the SEE countries and a case study of Serbia, Working papers 63, The wiiw Balkan Observatory, Vienna, Austria.

Jha, S., Sugiyarto, G., \& Vargas-Silva, C. (2010). The Global Crisis and the Impact on Remittancesto Developing Asia. Global Economic Review, 39 (1), 59-82. doi: https://doi.org/10.1080/12265081003696395

Kagochi, J. M., \& Kiambigi, M. (2012). Remittances' Influence on Housing construction demand in Sub-Saharan Africa: The case of Kenya. African Development Review, 24 (3), 255-265. https://doi.org/10.1111/j.1467-8268.2012.00321.x

Le, T. (2009). Trade, Remittances, Institutions, and Economic Growth. International Economic Journal, 23 (3), 391-408. doi: 10.1080/10168730903119443

Mallick, H. (2012). Inflow of remittances and private investment in India. The Singapore Economic Review, 57 (1), 1-22. https://doi.org/10.1142/S021759081250004X

Mughal, M. Y., \& Ahmed, J. (2014). Remittances and Business Cycles: Comparison of South Asian Countries. International Economic Journal, 28 (4), 513-541. https://doi.org/10.1080/10168737.2014.920895

Mughal, A. G., Cipusheva, H., \& Abazi, H. (2008), Migration, remittances, and the standards of living in the republic of Macedonia, [online access on 20/05/2017] https://www.seeu.edu.mk/files/research/magchah-report-final.pdf

Narayan, P., Narayan, S., \& Mishra, S. (2011). Do remittances induce inflation? Fresh evidence from developing countries. Southern Economic Journal, 77 (4), 914-933. https://doi.org/10.4284/0038-4038-77.4.914

Okodua, H., \& Olayiwola, W. K. (2013). Migrant workers' remittances and External trade balance in Sub-Sahara African countries. Internatinal Journal of Economics and Finance, 5 (3), 134-142. doi: 10.5539/ijef.v5n3p134 
Olubiyi, E. A. (2014). Trade, Remittances and Economic growth in Nigeria: Any causal relationship?. African Development Review, 26 (2), 274-285. https://doi.org/10.1111/1467-8268.12081

Petrou, K., \& Connell, J. (2014). Food, Morality and Identity: mobility, remittances and the translocal community in Paama, Vanuatu. Australia Geographer, 48 (2), 219-234. doi: https://doi.org/10.1080/00049182.2016.1204671

Prakash, K. A., \& Mala, A. (2015). Is the Dutch disease effect valid in relation to remittances and the real exchange rate in Fiji?. Journal of the Asia Pacific Economy, 21 (4), 571-577. doi: https://doi.org/10.1080/13547860.2016.1153225

Rausser, G., Strielkowski, W., Bilan, Y., \& Tsevukh, Y. (2018). Migrant Remittances and their Impact on the Economic Development of the Baltic States. Geographica Pannonica, 22 (3),165-175. doi: 10.5937/gp22-16988

Stratan, A., \& Chistruga, M. (2012). Economic consequences of remittances. Case of Moldova. Procedia Economics and Finance, 3, 1191-1195. doi: https://doi.org/10.1016/S22125671(12)00295-X

Trinh, P. T. T. (2014). The Impact of Exchange Rate Fluctuation on Trade Balance in the Short and Long Run: The Case of Vietnam. Journal of Southeast Asian Economies, 31 (3), 432452. doi: http://www.jstor.org/stable/43264738

Tung, L. T., Ly, P. T. M., Nhu, P. T. Q., Thanh, P. T., Anh, L. T., \& Phung, T. T. P. (2015). The Impact of Remittance Inflows on Inflation: Evidence in Asian and The Pacific Developing Countries. Journal of Applied Economic Sciences, 10(7), 1076-1084.

Vaaler, P. M. (2011). Immigrant remittances and the venture investment environment of developing countries. Journal of International Business Studies, 42 (9), 1121-1149. doi: https://doi.org/10.1057/jibs.2011.36

Vella, F., \& Verbeek, M. (1999). Two-step estimation of panel data models with censored endogenous variables and selection bias. Journal of Econometrics, 90 (2), 239-263. doi: https://doi.org/10.1016/S0304-4076(98)00043-8

World Bank. (2016a). Migration and Development: A role for the World Bank group, [online access 18/06/2017] http://pubdocs.worldbank.org/en/468881473870347506/Migrationand-Development-Report-Sept2016.pdf

World Bank. (2016b). Migration and Remittaces Factbook 2016 ( $3^{\text {th }}$ Edition). [online access 20/06/2017]https://openknowledge.worldbank.org/bitstream/handle/10986/23743/978146 4803192.pdf

World Bank. (2017). World Development Indicators online database, Washington, DC. [online access 15/10/2017]. Retrieved from http://data.worldbank.org/indicator 